\title{
ASSESSMENT OF SMALLHOLDER FARMER'S VULNERABILITY DUE TO CLIMATE CHANGE IN ARID AREAS OF PAKISTAN
}

\author{
SATTAR, R. S. ${ }^{1}-$ WANG, $.^{1 *}-$ TAHIR, M. N. $^{2}-$ CALDWELL, C. ${ }^{3}$ \\ ${ }^{I}$ College of Crop Sciences, Fujian Agriculture and Forestry University \\ Fuzhou, Fujian-350002, P.R. China \\ ${ }^{2}$ Faculty of Food Crops and Crop Sciences, PMAS-Arid Agriculture University \\ Rawalpindi, Murree Road, Pakistan \\ ${ }^{3}$ Faculty of Agriculture, Dalhousie University \\ P.O. Box 550, Truro B2N 5E3, Nova Scotia, Canada \\ *Corresponding author \\ e-mail: wsoloedu07@126.com; phone: +86-591-837-19641 \\ (Received $12^{\text {th }}$ Apr 2017; accepted $20^{\text {th }}$ Jun 2017)
}

\begin{abstract}
In developing countries, such as Pakistan, the food and financial security of smallholder farmers are increasingly threatened by climate change, contributing to considerable increases in input costs and market price volatility for agricultural commodities. This study aimed to identify and investigate factors contributing to smallholder farmers' vulnerability to climate changes and to develop vulnerability indices in Punjab province, Pakistan. Three different composite indices were used to assess the vulnerability of smallholder farmers to climate changes: Livelihood Vulnerability Index, Livelihood Vulnerability Index-Intergovernmental Penal on Climate Change, and Livelihood Effect Index. The weakness of social networks in Rawalpindi district is majorly important to enable the adoption of appropriate mitigating strategies. For both districts, lack of education had the highest effect on social vulnerability. Adoption of strategies towards mitigation of climate changes seems to be possible by the respondents in Chakwal district, with higher illiteracy rate, higher dependency ratio, and greater financial vulnerability. The natural and financial capital had the highest impact on the livelihoods of smallholder farmers in both districts. Ultimately, this research can provide a scientific basis for the decision-making process and risk analysis of climate change impacts in developing countries, where most of the smallholder farmers, as a major social group worldwide, are located.
\end{abstract}

Keywords: environmental change, livelihood, livelihood vulnerability index, sustainable development, Potohar

\section{Introduction}

Agriculture is one of the sectors most sensitive to climate change because any degree of climate change can be associated with severe negative impacts on agricultural production and related processes (Lin et al., 2007). Such impacts are predicted to be particularly harsh in the tropical countries, lowlands, and areas affected by reduced snowfall and melting glaciers. In the tropical countries, any increase in temperature can contribute to a considerable decrease in crop yields due to already reached the threshold of heat and drought tolerance by the crops (Burch et al., 2007). Lowlands can be adversely affected by flooding and soil salinization due to predicted sea level rise and groundwater salinization. The areas impacted by reduced snowfall and melting glaciers can face severe droughts due to a decrease in water availability for meeting crop water requirements (IFAD, 2013). 
For the last two decades, the vulnerability of agricultural production to climate change effects increasingly became the focus of comprehensive research (Tan, 2004). However, despite worldwide recognized the potential of climate change for negative impacts on agriculture, research work on assessment and mitigation of these impacts remains scarce in developing countries, particularly on smallholder farms (Morton, 2007; Ahmed and Schmitz, 2015). It is significantly important because smallholder farmers have been identified as most vulnerable to climate change impacts, both in developed and developing countries (Adger, 2006). Therefore, research on the implications of climate change on agriculture and decrease in farmers' livelihood vulnerability to these impacts in the most exposed regions, as mentioned above, is highly required for developing effective adaptation measures and ensuring sustainable agricultural development. Such research would also provide a scientific basis for the decision-making process and risk analysis of climate change impacts in the investigated locations (Tao et al., 2011).

Smallholder farmers are a distinct social group regarding numbers and food security. They are estimated at 400-450 million of world population and $87 \%$ of Asian population (Von Braun and Pandya-Lorch, 2007). They are also assessed as representing the insecure food half of global population (Nagayets, 2005; Sanchez and Swaminathan, 2005). The term "'Smallholder Agriculture', as used in under-developed countries, commonly defines rural producers who generate income from the family labor farming (Cornish, 1998) and hold less than 2 hectares (ha) of land (Csaki and de Haan, 2003). The food security is increasingly threatened by climate change effects, such as severe pest breakouts, extreme weather conditions, and water scarcity, contributing to considerable increases in input costs and market price volatility for agricultural commodities (O'Brien et al., 2004; Morton, 2007; Makondo et al., 2014) . In this light, and considering agriculture as primary source of their income, smallholder farmers are particularly vulnerable to climate change impacts. Such as the above mentioned ones, mainly due to high risk of yield losses, with further negative impacts not only on their food but also financial security and, ultimately, in their living conditions (Rosch and Hertel, 2010; McDowell and Hess, 2012)

Pakistan is a developing country where agriculture contributes $20.9 \%$ to GDP and $43.5 \%$ of the national labor force, but with generally little opportunity for income generation and small market returns in the rural areas (Farooq and Wasti, 2015). The climatic conditions are characterized by arid and hot climate, with the occurrence of droughts and floods negatively impacting on agricultural production (Yu et al., 2013). In this light, and considering the farmers' low level of awareness of climate changes, it can be deduced their high vulnerability to these changes and the need to assess this vulnerability.

In this context, this work aimed to identify and investigate factors contributing to smallholder farmers' vulnerability to climate changes and to develop and adapt vulnerability indices in two districts of arid region in Punjab province, Pakistan.

\section{Methods}

\section{Study area}

This study combines methods from different schools of climate change assessments to assess livelihood vulnerability in two districts, Chakwal and Rawalpindi, of the arid region in Pakistan. This region has been considered as having the considerable 
agricultural potential to reduce imports of agricultural commodities at the national level (Ijaz and Ahmad, 2006). Fragmentation characterizes the agricultural land, and the region contributes around 10 percent of national aggregated agricultural production (Ashraf et al., 2004). Chakwal district has an estimated population of 1.4 million within an area of $6.524 \mathrm{Km}^{2}$ (Rafique, 2015). There are 151989 farms in this district, out of which 65 percent are considered as smallholder farms and occupy 29 percent of the cultivated area (Pakistan-Bureau-of-Statistics, 2010). The climate is arid, characterized by hot and dry summers and cold and dry winters. The average annual rainfall is 880 $\mathrm{mm}$. The average temperature is $8^{\circ} \mathrm{C}$ during winter, rising to $42^{\circ} \mathrm{C}$ during summer. The landscape is diverse, with plains and hills (Sheikh, 2012a). Rawalpindi district has an estimated population of 4.7 million within an area of $5.285 \mathrm{Km}^{2}$ (Rafique, 2015). There are 182186 agricultural farms in the district, out of which 85 percent are smallholder farms occupying 41 percent of the total cultivated area (Pakistan-Bureau-of-Statistics, 2010). The climate varies from district to district, as winter is remarkably cold, and summer is mild in Murree Tehsil, whereas summer is tolerably hot, and winter is mild in Gujar Khan and Rawalpindi tehsils. The average annual rainfall in the district is $\mathbf{1 5 5 0}$ mm. The landscape is dominated by plains in Gujjar Khan and Rawalpindi tehsils (Sheikh, 2012b). In both districts, the major known crops are wheat, groundnut, rapeseed, and mustard, with additional vegetables such as onion, potato, tomato and peas.

\section{Data collection and analyses}

Household survey, of 120 randomly selected smallholder farms with less than 2 hectares, was used for data collection. Three different composite indices were used to assess the vulnerability of smallholder farmers to climate change: Livelihood Vulnerability Index (LVI), Livelihood Vulnerability Index- Intergovernmental Penal on Climate Change (LVI- IPCC), and Livelihood Effect Index (LEI). The methodology used for calculating the indices was adapted from (Hahn et al., 2009) and (Khajuria and Ravindranath, 2012), so as to include specific climatic and contextual conditions (Parry et al., 2007). In this study the index LEI is constructed on Sustainable Livelihood Framework to understand vulnerability regarding livelihood. The framework for sustainable livelihoods has been presented in Fig. 1 which shows that processes and structures, livelihood outcome and livelihood strategies of a community are influenced by the vulnerability context and that is determining factor for sustainable livelihoods. More precisely, in Pakistan, the financial security of smallholder farmers is seriously threatened by the occurrence of droughts and floods negatively impacting on agricultural production, with further negative impacts on market price volatility for agriculture commodities, as well as by heavy reliance on agriculture as a single source for income generation. Knowing that reduced financial resources and lack of alternative sources for income generation have been identified as contributors to environmental degradation (Tripathi and Vasan, 2014), two more components, Finance and Knowledge and skills, have been taken into consideration, besides the original ones, for calculating vulnerability more precisely. 


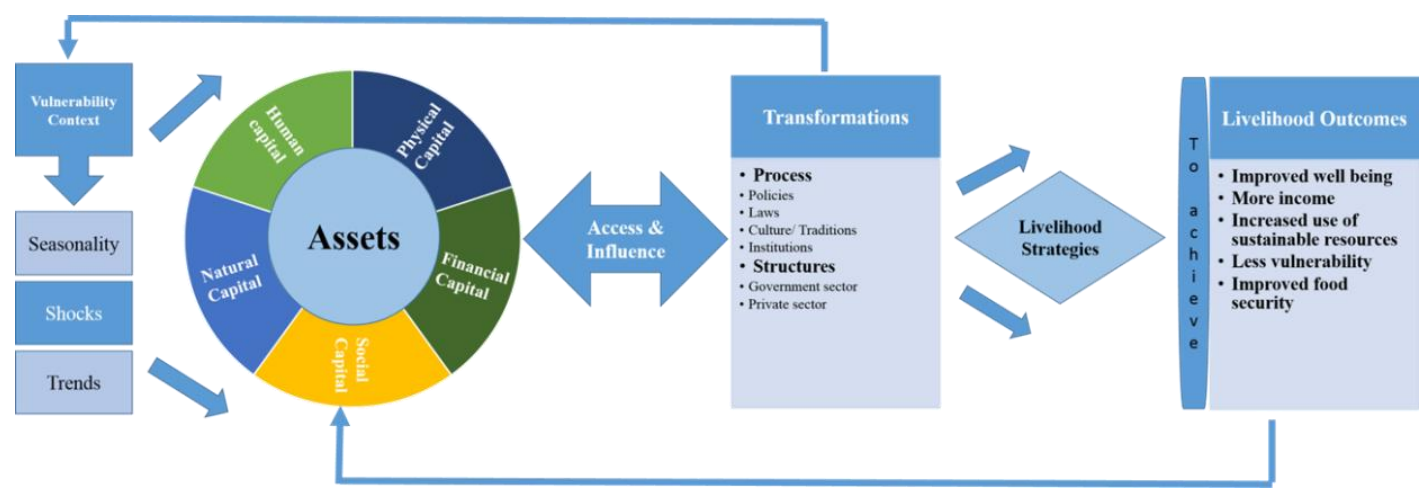

Figure 1. Framework for Sustainable livelihoods

\section{Calculating Livelihood Vulnerability Index}

Both internal and external factors relating to smallholder farmer's vulnerability to climate change were taken into consideration for calculating LVI. Balance weighted approach was employed to calculate LVI.

The LVI includes nine essential elements: Socio-Demographic Profile (SDP), Livelihood Strategies (LS), Finance (Fi), Knowledge and Skills (KS), Social Networks $(\mathrm{KS})$, Health $(\mathrm{H})$, Water $(\mathrm{W})$, Food $(\mathrm{F})$, and Natural Vulnerability and Climate Variability (NVCV). Each of these elements is comprised of several sub-components identified in the literature reviewed and presented in Table 1. Because of different measuring scale of each of the sub-components, it was first necessary to standardize each of them as an index by using equation (1).

$$
\text { Index } s_{d}=\frac{S_{d}-S_{\min }}{S_{\max }-S_{\min }}
$$

Where $S_{d}$ is the originally observed value of the sub-component for district $d$, and $S_{\min }$ and $S_{\max }$ are the minimum and maximum values, respectively, for each subcomponent determined using data from both districts. After each sub-component, has been standardized, the obtained values were averaged by using equation (2) to calculate the value of the major component.

$$
M_{d}=\frac{\sum_{i=1}^{n} \operatorname{lndex} s_{d^{i}}}{n}
$$

Where $M_{d}$ represents one of the nine major components for district $d$, denotes the sub-components, indexed by $i$, that make up each major component, and $n$ is the number of sub-components in each major component. The resulted values of each of the nine principal components were averaged by using the following equation (3) to calculate LVI at the district level.

$$
L V I_{d}=\frac{\sum_{i=1}^{9} w_{M i} M_{d i}}{\sum_{i=1}^{9} w_{M i}}
$$


Where $\mathrm{LVI}_{\mathrm{d}}$ denotes the Livelihood Vulnerability Index for District d, obtained by the weighted average of the nine major components. The weights of each major component, $\mathrm{w}_{\mathrm{Mi}}$, were determined by the number of sub-components of each major component and are included to ensure that all sub-components contribute equally to the overall LVI (Sullivan, 2002; Hahn et al., 2009; González Botero et al., 2013). In this study, the LVI is scaled from 0 (least vulnerable) to 1 (most vulnerable).

\section{Calculating Livelihood Vulnerability Index- Intergovernmental Penal on Climate Change}

Exposure, Adaptive capacity and Sensitivity are the three contributing factors to livelihood vulnerability, according to IPCC definition of vulnerability to climate change. Organization and arrangements of the nine major components used to calculate LVI-IPCC is presented in Table 2. The sub-components in Table 1, and equation (1), (2), and (3) were used for the calculation of LVI-IPCC. The LVI-IPCC deviates from the LVI when the major components are combined. The major components were connected according to the categorization scheme in Table 2, rather than to merge into the LVI in one step, by using the following equation (4).

$$
L V I_{d i}=\frac{\sum_{i=1}^{n} w_{M i} M_{d i}}{\sum_{i=1}^{n} w_{M i}}
$$

Where $\mathrm{CF}_{\mathrm{d}}$ represents IPCC-defined contributing factor (exposure, adaptive capacity, or sensitivity) for district $\mathrm{d}, \mathrm{M}_{\mathrm{di}}$ denotes major components of the district $\mathrm{d}$ indexed by $\mathrm{i}$; $\mathrm{w}_{\mathrm{Mi}}$ indicates the weight of each major component, and $\mathrm{n}$ is the number of major components in each contributing factor. The calculated contributing factors were combined by using the following equation (5)

$$
L V I-I P C C_{d}=\left(e_{d}-a_{d}\right) \times S_{d}
$$

Where LVI-IPCCd indicates the vulnerability index for district $\mathrm{d}$ calculated by using IPCC vulnerability framework, whereas ed, ad, and sd represent the scores of exposure, adaptive capacity and sensitivity for district $d$ respectively. The scale for LVI-IPCC ranges from -1 (least vulnerable) to 1(most vulnerable). 
Table 1. Major and sub-components with the explanation and source for comprising LVI for two districts

\begin{tabular}{|c|c|c|c|}
\hline $\begin{array}{c}\text { Major } \\
\text { Components }\end{array}$ & Sub-components & Explanation of Sub-components & Source \\
\hline $\begin{array}{l}\text { Socio } \\
\text { Demographic } \\
\text { Profile }\end{array}$ & $\begin{array}{l}\text { Dependency ratio } \\
\text { Female- headed household } \\
\text { Age of the household head } \\
\text { Households head not } \\
\text { attended school } \\
\text { Household family size } \\
\text { Number of years of } \\
\text { employment in agriculture }\end{array}$ & $\begin{array}{l}\text { Ratio of the population under } 15 \text { and over } 65 \text { years of age to } \\
\text { the population between } 16 \text { and } 64 \text { years of age. } \\
\text { If a male head is away from the home }>6 \text { months per year, the } \\
\text { female is counted as the head of the household. } \\
\text { Average age of the household head } \\
\text { Percentage of households where the head of the household } \\
\text { reports that they have attended } 0 \text { years of school. } \\
\text { Average family members in household } \\
\text { Average agriculture experience of the household head }\end{array}$ & $\begin{array}{l}\text { (Hahn et al., 2009, González Botero et } \\
\text { al., 2013, DHS, 2006) } \\
\text { (Hahn et al., 2009, González Botero et } \\
\text { al., 2013, DHS, 2006) } \\
\text { (González Botero et al., 2013) } \\
\text { (Hahn et al., 2009, González Botero et } \\
\text { al., 2013, DHS, 2006) } \\
\text { (González Botero et al., 2013) } \\
\text { (González Botero et al., 2013) }\end{array}$ \\
\hline $\begin{array}{l}\text { Livelihood } \\
\text { Strategies }\end{array}$ & $\begin{array}{l}\text { Household family members } \\
\text { working outside/ different } \\
\text { community } \\
\text { Household totally dependent } \\
\text { on agriculture } \\
\text { Average agricultural } \\
\text { Livelihood diversification } \\
\text { index } \\
\text { Cultivated Land }\end{array}$ & $\begin{array}{l}\text { Percentage of households that report at least } 1 \text { family member } \\
\text { who works outside of the community for their primary work } \\
\text { activity } \\
\text { Percentage of households that report only agriculture as a } \\
\text { source of income. } \\
\text { The inverse of (the number of agricultural livelihood activities } \\
+1 \text { ) reported by a household, e.g., A household that farms, } \\
\text { raises animals, and collects natural resources will have a } \\
\text { Livelihood, Diversification Index }=1 /(3+1)=0.25 \text {. } \\
\text { Average of the total land cultivated by the Household }\end{array}$ & $\begin{array}{l}\text { (Hahn et al., 2009, González Botero et } \\
\text { al., 2013) } \\
\text { (González Botero et al., 2013) } \\
\text { (Hahn et al., 2009, González Botero et } \\
\text { al., 2013, DHS, 2006) }\end{array}$ \\
\hline $\begin{array}{l}\text { Knowledge } \\
\text { and Skills }\end{array}$ & $\begin{array}{l}\text { Farmers not having T. V } \\
\text { Farmers don't share } \\
\text { knowledge with each other } \\
\text { Farmers think they lack in } \\
\text { education }\end{array}$ & $\begin{array}{l}\text { Percent of household not having T.V at home } \\
\text { Percent of households don't participate in knowledge exchange } \\
\text { with others } \\
\text { Percent of households that think they lack in education }\end{array}$ & $\begin{array}{l}\text { (González Botero et al., 2013) } \\
\text { (González Botero et al., 2013) } \\
\text { (González Botero et al., 2013) }\end{array}$ \\
\hline
\end{tabular}




\begin{tabular}{|c|c|c|c|}
\hline Finance & $\begin{array}{l}\text { Household having more } \\
\text { expense than income } \\
\text { Household family member } \\
\text { work at developed place } \\
\text { Farmers taken loan }\end{array}$ & $\begin{array}{l}\text { Percent of household having more expenditures than income } \\
\text { Percent of household with any family member working } \\
\text { developed place not farming } \\
\text { Percent of Household who taken loan in past five years }\end{array}$ & $\begin{array}{l}\text { (González Botero et al., 2013) } \\
\text { (González Botero et al., 2013) } \\
\text { (Corbett, 1988, Tewari and } \\
\text { Bhowmick, 2014) }\end{array}$ \\
\hline Food & $\begin{array}{l}\text { Farmers depend on land for } \\
\text { food } \\
\text { Average Crop Diversity } \\
\text { Index } \\
\text { Farmers that don't save crop } \\
\text { Farmers that don't save seed }\end{array}$ & $\begin{array}{l}\text { Percentage of households that get their food primarily from } \\
\text { their personal farms } \\
\text { The inverse of (the number of crops grown by a household }+1 \text { ) } \\
\text { Percentage of households that do not save crops } \\
\text { Percentage of households that do not save seed }\end{array}$ & $\begin{array}{l}\text { (González Botero et al., 2013, Hahn et } \\
\text { al., 2009) } \\
\text { (Hahn et al., 2009, Tewari and } \\
\text { Bhowmick, 2014, González Botero et } \\
\text { al., 2013) } \\
\text { (Hahn et al., 2009; Tewari and } \\
\text { Bhowmick, 2014) } \\
\text { (Hahn et al., 2009; Tewari and } \\
\text { Bhowmick, 2014) }\end{array}$ \\
\hline Health & $\begin{array}{l}\text { Household family member } \\
\text { with chronic diseases } \\
\text { Farmers receiving treatment } \\
\text { in hospitals } \\
\text { Time needed to reach } \\
\text { hospital }\end{array}$ & $\begin{array}{l}\text { Percentage of households that report at least } 1 \text { family member } \\
\text { with chronic illness } \\
\text { Percentage of households receiving treatment from } \\
\text { government or private hospitals } \\
\text { Average time it takes the households to get to the nearest } \\
\text { health facility. }\end{array}$ & $\begin{array}{l}\text { (Hahn et al., 2009, Tewari and } \\
\text { Bhowmick, 2014, DHS, 2006) } \\
\text { (Tewari and Bhowmick, 2014, Bhat et } \\
\text { al., 2007) } \\
\text { (Hahn et al., 2009) }\end{array}$ \\
\hline Water & $\begin{array}{l}\text { Farmers utilize natural water } \\
\text { source } \\
\text { Farmers that store water } \\
\text { Household with depleted } \\
\text { water source } \\
\text { Household without water } \\
\text { supply }\end{array}$ & $\begin{array}{l}\text { Percentage of households that report a river, lake, or wells as } \\
\text { their primary water source. } \\
\text { Percentage of households that store water for household } \\
\text { activities and drinking } \\
\text { Percent of households reported their water source depleted } \\
\text { Percentage of households that report that water is not available } \\
\text { at their primary water source everyday }\end{array}$ & $\begin{array}{l}\text { (Hahn et al., 2009, DHS, 2006) } \\
\text { (Tewari and Bhowmick, 2014) } \\
\text { (González Botero et al., 2013) } \\
\text { World Bank (1997); (Hahn et al., } \\
\text { 2009, González Botero et al., 2013, } \\
\text { Tewari and Bhowmick, 2014) }\end{array}$ \\
\hline $\begin{array}{l}\text { Social } \\
\text { networks }\end{array}$ & $\begin{array}{l}\text { Household received help } \\
\text { and given help }\end{array}$ & $\begin{array}{c}\text { APPLIED ECOLOGY AND ENVIRONMENTAL RESEARCH 15(4):291-312. } \\
\text { http://www.aloki.hu • ISSN } 15891623 \text { (Print) • ISSN } 17850037 \text { (Online) } \\
\text { DOI: http://dx.doi.org/10.15666/aeer/1504_291312 } \\
\text { @ 2017, ALÖKI Kft., Budapest, Hungary }\end{array}$ & (Hahn et al., 2009, DHS, 2006) \\
\hline
\end{tabular}




\begin{tabular}{|c|c|c|c|}
\hline & $\begin{array}{l}\text { Household borrowed or lent } \\
\text { money } \\
\text { Household not affiliated to } \\
\text { any organization }\end{array}$ & $\begin{array}{l}\text { Percentage of households who borrowed more money } \\
\text { than it lent in the past month } \\
\text { Percent of the households where none of the family member is } \\
\text { affiliated with any social institution or organization }\end{array}$ & $\begin{array}{l}\text { World Bank (1998); (Hahn et al., } \\
\text { 2009) } \\
\text { (González Botero et al., 2013) }\end{array}$ \\
\hline $\begin{array}{l}\text { Natural } \\
\text { Vulnerability } \\
\text { and Climate } \\
\text { Variability }\end{array}$ & $\begin{array}{l}\text { Household reported less rain } \\
\text { during last few years } \\
\text { Household reported more } \\
\text { drought } \\
\text { Household reported unusual } \\
\text { rains } \\
\text { Household reported increase } \\
\text { in temperature } \\
\text { Household feel problems in } \\
\text { agriculture due to climate } \\
\text { change } \\
\text { Household don't receive } \\
\text { warnings regarding severe } \\
\text { weather } \\
\text { Household change in crop } \\
\text { choices/ calendar due to } \\
\text { climate change }\end{array}$ & $\begin{array}{l}\text { Percent of household reported less rain during past few years } \\
\text { Percent of household reported more drought in past few years } \\
\text { Percent of household reported unusual rains in past few years } \\
\text { Percent of household reported increase in temperature in past } \\
\text { few years } \\
\text { Percent of household feel problems in agriculture due to } \\
\text { climate change } \\
\text { Percent of Household don't receive warnings regarding severe } \\
\text { weather } \\
\text { Percent of household that change their crop choice due to } \\
\text { climate change }\end{array}$ & $\begin{array}{l}\text { (González Botero et al., 2013) } \\
\text { (González Botero et al., 2013) } \\
\text { (González Botero et al., 2013) } \\
\text { (González Botero et al., 2013) } \\
\text { (González Botero et al., 2013) } \\
\text { (González Botero et al., 2013, Hahn et } \\
\text { al., 2009, Tewari and Bhowmick, } \\
\text { 2014) } \\
\text { (González Botero et al., 2013) }\end{array}$ \\
\hline
\end{tabular}


Table 2. Categorization of the major components for calculation of LVI-IPCC

\begin{tabular}{c|l}
\hline Contributing Factors & \multicolumn{1}{|c}{ Major Components } \\
\hline Exposure & $\begin{array}{l}\text { Natural vulnerability and climate variability } \\
\text { Socio demographic profile, Livelihood strategies, Knowledge } \\
\text { and skills, Finance, Social networks } \\
\text { Adaptive Capacity } \\
\text { Sensitivity }\end{array}$ \\
\hline
\end{tabular}

\section{Calculating Livelihood Effect Index}

The LEI was determined with the index values of five indicators, namely Human Capital, Natural Capital, Social Capital, Financial Capital and Physical capital. Categorization of the major components into these indicators is shown in Table 3. Each value of the five indicators was calculated by using the following equation (6).

$$
C v_{d}=\frac{\sum_{i=1}^{n} L_{d i}}{n}
$$

Where $\mathrm{Cv}_{\mathrm{d}}$ is the value of each capital of LEI for district $d$, whereas $\mathrm{L}_{\mathrm{di}}$ and $n$ represent the value of each effect dimension for capital $i$ of district $d$ and total subdimensions forming a capital. After calculating the value of each capital, these values were averaged to compute the LEI of the district by using the equation (7).

$$
L E I_{d}=\frac{\Sigma_{i=1}^{\mathrm{s}} W_{i} C v_{d i}}{\Sigma W_{i}}
$$

Where $\mathrm{W}_{\mathrm{i}}$ and $\mathrm{Cv}_{\mathrm{di}}$ indicate the weight of each capital and value of each capital of district $d$ indexed by $i$. The LEI scale ranged from 0 (least affected) to 1 (most affected).

Table 3. Arrangements of major components into different indicators for calculation of LEI

\begin{tabular}{l|l}
\hline Indicators & Effect Dimensions \\
\hline Human Capital & Health, Food, Knowledge and Skills \\
Social Capital & Socio demographic profile, Social networks \\
Natural Capital & Water, Natural vulnerability and climate variability \\
Financial Capital & Finances \\
Physical Capital & Livelihood strategies \\
\hline
\end{tabular}

\section{Results}

\section{Livelihood Vulnerability Index (LVI)}

The average overall indexed values of socio-demographic profile vulnerability index (SDPVI) indicated Chakwal as more vulnerable (0.424) compared to Rawalpindi district (0.356). Among the 120 farmers interviewed in both districts, the average age of the respondents was 51 years. The average percentage of females was 7 and 8 , respectively. The average number of years of employment in farming activities was 29 for both districts. 
The average indexed value of the dependency ratio was higher (0.334) for Chakwal compared to Rawalpindi district (0.259). There was a slight difference in the preindexed value for female family heads in Chakwal $(7 \%)$ and Rawalpindi district (8\%). The average pre-indexed value for household heads not attended school was higher in Chakwal (70\%), as compared to Rawalpindi district (48\%). The average pre-indexed value for household family size in both districts was slightly different, with 7.37 persons in Chakwal and 8.07 persons in Rawalpindi district. The average pre-indexed value for the number of years of employment in agriculture was higher in Chakwal (31 years) compared with Rawalpindi District (25 years).

The average overall indexed value of Livelihood strategies vulnerability index (LSVI) was slightly higher for Rawalpindi (0.487) compared with Chakwal district (0.478), whereas a higher percent of farmers in Chakwal (0.71) were solely dependent on agriculture for income generation compared with Rawalpindi district (0.68). The average indexed value of family members employed outside the community was higher for Rawalpindi (0.479) compared to Chakwal district (0.306). The average indexed value for livelihood agricultural diversification index was lower for Rawalpindi (0.167) compared to Chakwal district (0.370). Pre-indexed values showed differences in terms of farmer's family members who are working outside, or in a different community (31 percent in Chakwal and 48 percent in Rawalpindi), percentage of farmers entirely dependent on agriculture (71 percent in Chakwal and 68 percent in Rawalpindi), along with average livelihood diversification index (0.311 in Chakwal and 0.250 in Rawalpindi). While slightly low differences were seen in terms of average cultivated land (3.1 and 3.3 acres in Chakwal and Rawalpindi district, respectively).

The average indexed value for knowledge and skills vulnerability index (KSVI) was slightly higher in Chakwal (0.293) compared with Rawalpindi district (0.246). The average pre-indexed values of KSVI subcomponents indicated very low percentage of farmers not having T.V. (six percent in Chakwal and two percent in Rawalpindi district, respectively), as well as low percentage of farmers who don't share knowledge with each other (four percent in Chakwal and eleven percent in Rawalpindi district, respectively). There was a considerable percentage of farmers who think they lack education (78 percent in Chakwal and 61 percent in Rawalpindi district, respectively).

The average indexed value of FiVI was higher for Rawalpindi (0.593) compared with Chakwal district (0.461). The average pre-indexed values of FiVI indicated a considerable percentage of farmers having more expenses than their income (95.8 percent in Chakwal and 83 percent in Rawalpindi district, respectively) and a comparably low percentage of household family members who worked at developed place (23.6 percent in Chakwal and 56 in Rawalpindi district, respectively. The average pre-indexed value for the percentage of farmers who took loans was considerably higher in Rawalpindi (39 percent) compared with Chakwal district (19 percent).

The average indexed value of the Food Vulnerability Index (FVI) indicated a rather low effect on the vulnerability in Chakwal (0.299) and Rawalpindi (0.349) district. The average pre-indexed value for the percentage of household depending on land for food was higher in Chakwal (71 percent) compared with Rawalpindi (56 percent) district. Similarly, the average indexed value for the same FVI sub-component was higher in Chakwal (0.71) compared with Rawalpindi (0.56) district. The percentage of farmers who don't save crop and seed was low in Chakwal (3.3 and 28.6 percent respectively) as compared to Rawalpindi (8.9 and 58.1 percent respectively) district. 
The average overall indexed value for the health vulnerability index (HVI) value was slightly a higher for Rawalpindi (0.406) compared with Chakwal (0.393) district. The average pre-indexed values of HVI subcomponents indicated higher percentage of household family members with chronic diseases in Chakwal (31 percent) compared with Rawalpindi (21 percent) district, but a comparably lower percentage of farmers receiving treatment in hospitals in Chakwal (37 percent) compared with Rawalpindi (49 percent) district. The average pre-indexed value for the recorded time needed to reach the hospital was higher for Chakwal (150 minutes) compared with Rawalpindi (121 minutes) district.

The average overall indexed value for the water vulnerability index (WVI) was slightly higher for Chakwal (0.453) compared with Rawalpindi (0.396) district. The average pre-indexed values of WVI sub-components indicated considerably low percentage of farmers who utilized natural water source ( 8 percent in Chakwal and 5 percent in Rawalpindi district, respectively); a moderate percentage of farmers who stored water (29 percent in Chakwal, and 33 percent in Rawalpindi district); and considerably high percentages of farmers who complained that their water source was depleted (48 percent in Chakwal, and 69 percent in Rawalpindi district) and of farmers living without water supply (96 percent in Chakwal, and 51.4 percent in Rawalpindi district).

The average overall indexed value for the social networks vulnerability index (SNVI) was slightly higher for Chakwal (0.519) compared with Rawalpindi (0.476) district. The average pre-indexed values of SNVI sub-components also indicated slight differences in the ratio of farmers not receiving and giving help (1.31 in Chakwal, and 1.35 in Rawalpindi district, respectively), the ratio of farmers who borrowed and lent money (1.5 in Chakwal, and 2 in Rawalpindi district, respectively). The average pre-indexed value for the percentage of farmers not affiliated with any organization was higher in Chakwal (82 percent) compared with Rawalpindi (69 percent) district.

The average overall indexed value for the natural vulnerability and climate variability vulnerability index (NVCVVI) was high for both Chakwal (0.777) and Rawalpindi (0.813) district. The average pre-indexed values of NVCVVI subcomponents indicated considerably high percentages of farmers, reporting reduced rainfall during the last year (61 and 81 percent), severe drought (79 and 88 percent), and unusual rain (81 and 85 percent); as well as an increase in temperature (85 and 96 percent) in Chakwal and Rawalpindi district, respectively. Similarly, it was observed that problems in agriculture due to climate change ( 82 and 93 percent), lack of warnings regarding severe weather ( 88 and 51 percent), change in crop choices or crop calendar (68 and 75 percent) in Chakwal and Rawalpindi district, respectively. However, these values, except for warning regarding severe weather, were higher for Rawalpindi compared with Chakwal.

The overall average indexed LVI value was higher for Rawalpindi (0.493) compared with Chakwal (0.479) district. The average indexed values of the nine major components of LVI (SDP, LS, KS, Fi, F, H, W, SN and NVCV) for both districts are also illustrated in Fig. 2 which indicates KSVI as one of the major components with moderate effect on vulnerability. Likewise, Fig. 2 also indicated FiVI as one of the major components with considerable effect on the vulnerability in both districts. 


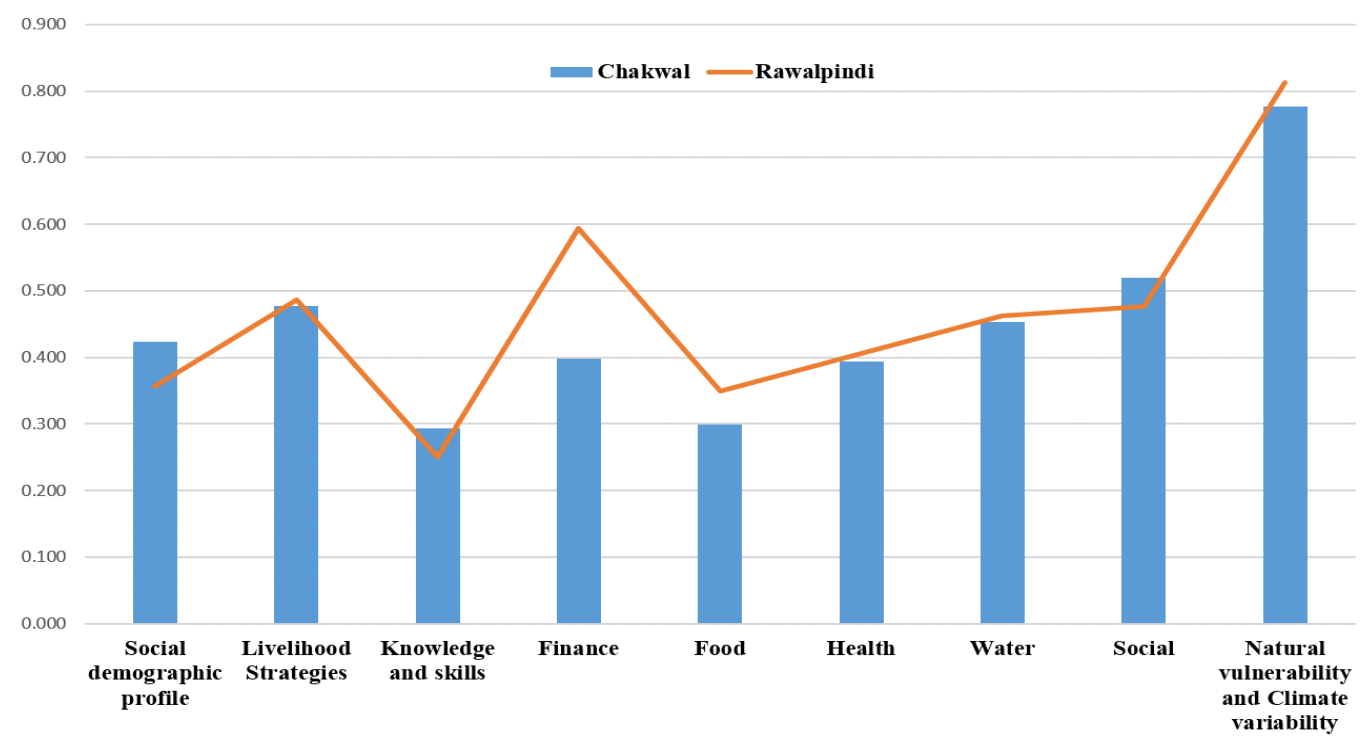

Figure 2. Major components of LVI for both districts

\section{Livelihood vulnerability index- Intergovernmental Panel on Climate Change (LVI- IPCC)}

The overall average indexed values of LVI-IPCC were slightly different for Chakwal (0.106) and Rawalpindi (0.089) district. The average indexed values of the three contributing factors (Exposure, Adaptive Capacity, and Sensitivity) indicated slight differences between the two districts in terms of exposure (0.777 and 0.813$)$, adaptive capacity (0.498 and 0.579) and sensitivity (0.381 and 0.382) in Chakwal and Rawalpindi district, respectively. The average indexed values of the three contributing factors, are also illustrated in Fig. 3, indicate that district Chakwal has the more adaptive capacity by showing lower vulnerability index compared with Rawalpindi district, whereas people of Rawalpindi are more exposed to climate change compared with Chakwal district. Regarding sensitivity, both districts are shown to be equally sensitive to climate change.

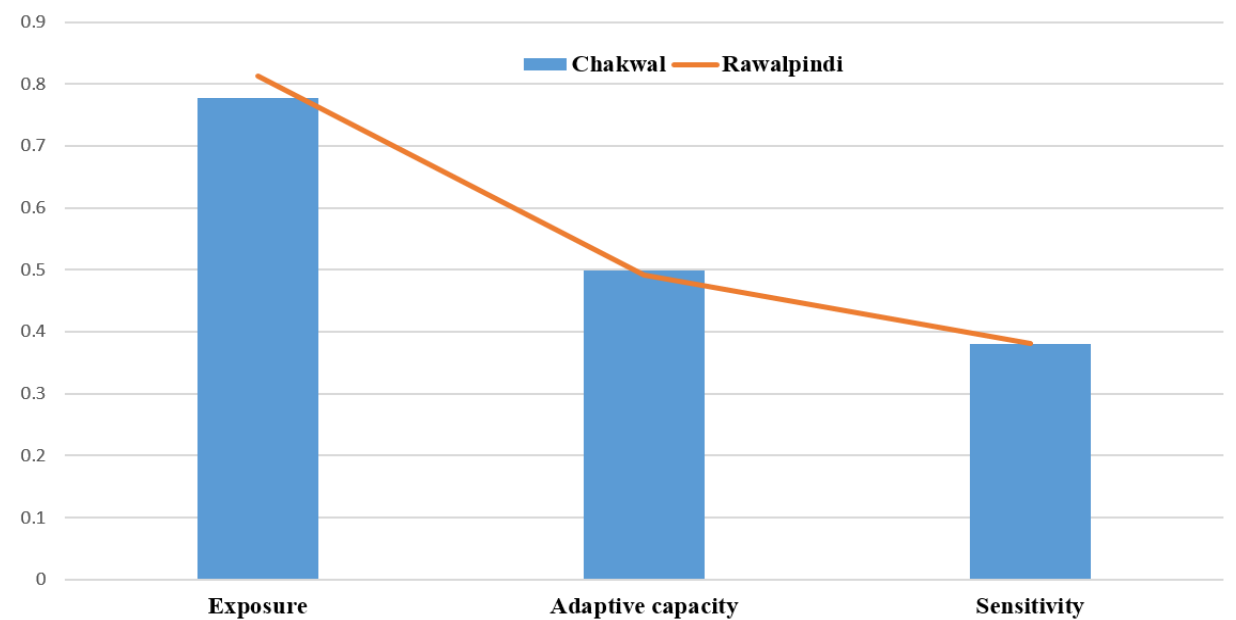

Figure 3. Contributing factors of LVI-IPCC for both districts 


\section{Livelihood Effect index (LEI)}

The average overall indexed value of LEI was a little difference for Chakwal (0.454) and Rawalpindi (0.474) district. The major components of LEI are described in Table 3 and the average pre-indexed, and indexed values of these components are presented in Table 4. The arrangement of major components into different indicators used for the calculation of LEI is described in Table 3. The average overall indexed value for the human capital was slightly higher in Rawalpindi (0.341) compared with Chakwal (0.326) district. The average overall indexed value for the social capital was slightly higher for Chakwal (0.455) compared with Rawalpindi (0.396) district. The average overall indexed values showed no, or very little, difference for the natural capital $(0.659$ and 0.685$)$, the financial capital (0.398 and 0.593) and the physical capital (0.478 and 0.487) in both Chakwal and Rawalpindi districts, respectively.

The average overall indexed values for these indicators are also illustrated in Fig. 4 which showed both districts are more vulnerable to natural capital and less to human capital. Physical capital contributed almost equally to the vulnerability in both districts. People of Rawalpindi district were more vulnerable to financial capital while social capital contributed to vulnerability more in Chakwal compared to Rawalpindi district.

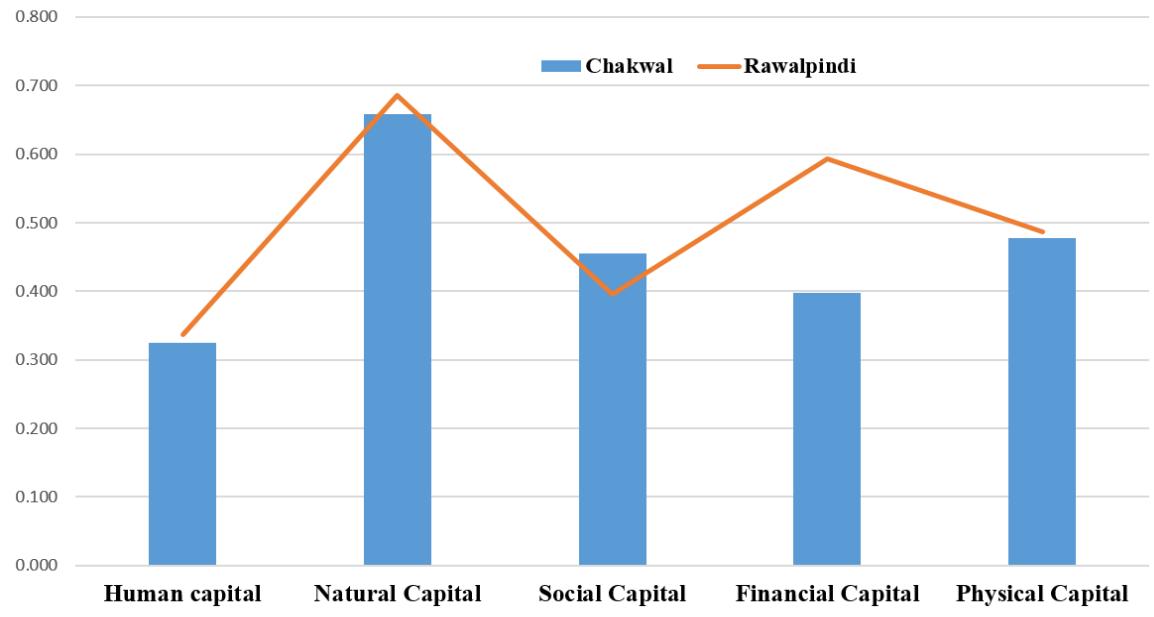

Figure 4. Vulnerability indicators of LEI for both districts 
Table 4. Sub-components, major components and overall LVI, LVI-IPCC, and LEI values for both districts in Pakistan

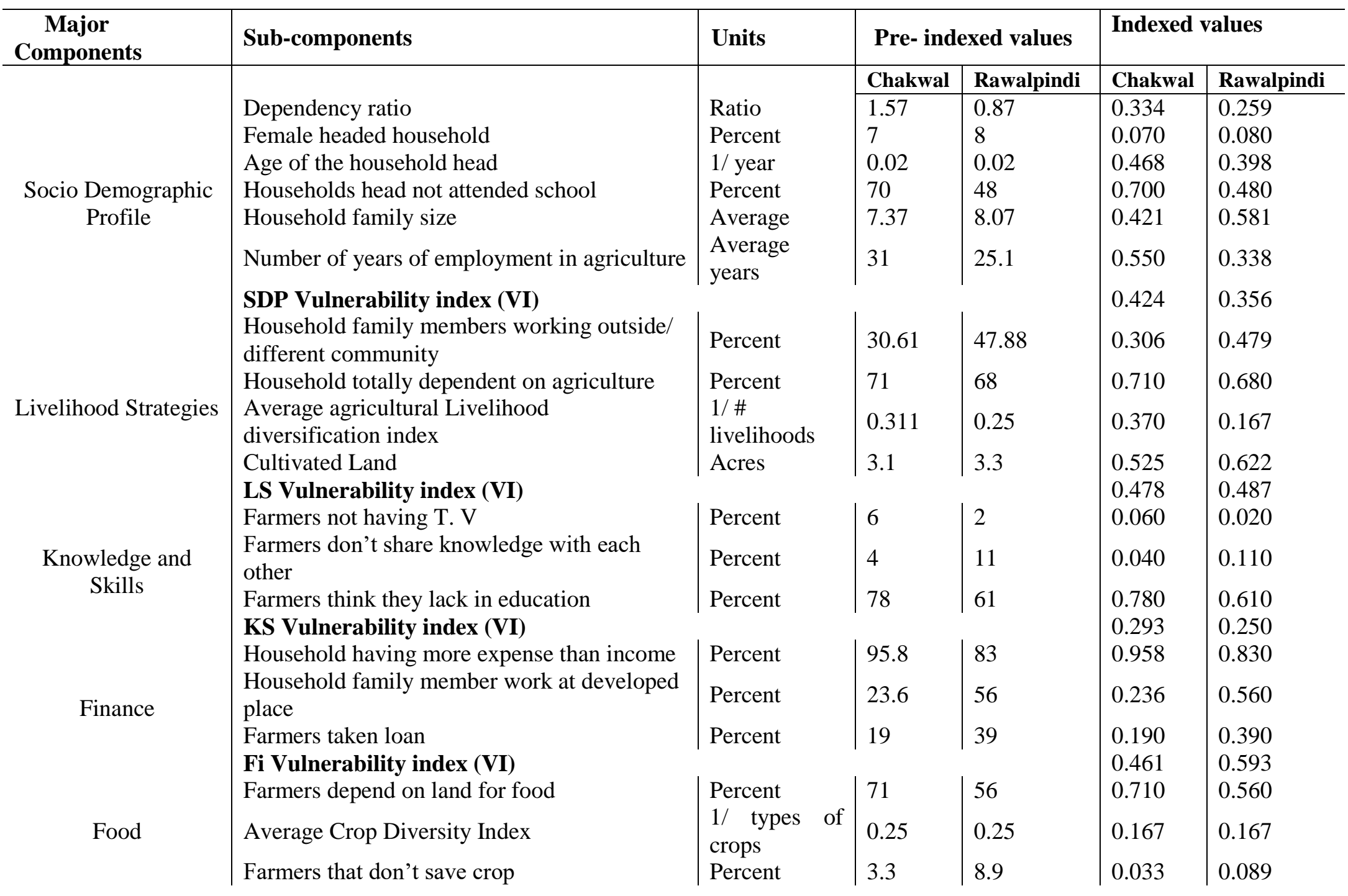


Health

Water

Social networks

Natural Vulnerability and Climate Variability
Farmers that don't save seed

\section{F Vulnerability index (VI)}

Household family member with chronic

diseases

Farmers receiving treatment in hospitals

Time needed to reach hospital

H Vulnerability index (VI)

Farmers utilize natural water source

Farmers that store water

Household with depleted water source

Household without water supply

W Vulnerability index (VI)

Household received help and given help

Household borrowed or lent money

Household not affiliated to any organization

SN Vulnerability index (VI)

Household reported less rain during last few

years

Household reported more drought

Household reported unusual rains

Household reported increase in temperature

Household feel problems in agriculture due to

climate change

Household don't receive warnings regarding

severe weather

Household change in crop choices/ calendar

due to climate change

NVCV Vulnerability index (VI)

LVI

LVI-IPCC

LEI

\begin{tabular}{|c|c|c|c|c|}
\hline Percent & 28.6 & 58.1 & $\begin{array}{l}0.286 \\
0.299\end{array}$ & $\begin{array}{l}0.581 \\
0.349\end{array}$ \\
\hline Percent & 31 & 21 & 0.310 & 0.210 \\
\hline Percent & 37 & 49 & 0.370 & 0.490 \\
\hline Minutes & 150 & 121 & $\begin{array}{l}0.500 \\
0.393\end{array}$ & $\begin{array}{l}0.517 \\
0.406\end{array}$ \\
\hline Percent & 8 & 5 & 0.080 & 0.050 \\
\hline Percent & 29 & 33 & 0.290 & 0.330 \\
\hline Percent & 48 & 69 & 0.480 & 0.690 \\
\hline Percent & 96 & 51.4 & $\begin{array}{l}0.960 \\
0.453\end{array}$ & $\begin{array}{l}0.514 \\
0.396\end{array}$ \\
\hline Ratio & 1.31 & 1.35 & 0.437 & 0.338 \\
\hline Ratio & 1.5 & 2 & 0.300 & 0.400 \\
\hline Percent & 82 & 69 & $\begin{array}{l}0.820 \\
0.519\end{array}$ & $\begin{array}{l}0.690 \\
0.476\end{array}$ \\
\hline Percent & 61 & 81 & 0.610 & 0.810 \\
\hline Percent & 79 & 88 & 0.790 & 0.880 \\
\hline Percent & 81 & 85 & 0.810 & 0.850 \\
\hline Percent & 85 & 96 & 0.850 & 0.960 \\
\hline Percent & 82 & 93 & 0.820 & 0.930 \\
\hline Percent & 88 & 51 & 0.880 & 0.510 \\
\hline Percent & 68 & 75 & 0.680 & 0.750 \\
\hline & & & 0.777 & 0.813 \\
\hline & & & 0.479 & 0.493 \\
\hline & & & 0.106 & 0.123 \\
\hline & & & 0.454 & 0.474 \\
\hline
\end{tabular}




\section{Discussion}

\section{Livelihood Vulnerability Index (LVI)}

The results for SDPVI indicated Chakwal as more vulnerable compared with Rawalpindi district. The higher average overall indexed value of SDPVI for Chakwal district was mostly due to higher average pre-indexed values for the dependency ratio, household head without education, and many years of employment in agriculture, as well as to the indexed value of the household head. This reads as the farmers in Chakwal district were mostly in the range of age not allowing off-farm employment and self-sufficiency (Hahn et al., 2009; González Botero et al., 2013; DHS, 2006), illiterate, and could only be employed in agriculture, which is known as a sector associated with low income in Pakistan. Among these sub-components, lack of education registered the highest values for both districts and therefore had the highest effect on social vulnerability. This is because the lack of education was found to be associated with less income enhancing and diversification opportunity, generally low levels of income and social exclusion (Van der Berg, 2002; Green, 2006; Gebru and Beyene, 2012). The percentage of female farmers showed little differences in both districts, as females were mostly recorded as household head when husbands or sons lived off-farm for more than six months. The similarity of average pre-indexed values for the percentage of the female household head was due to similar trends of males working outside the community.

The results for LSVI indicated Chakwal and Rawalpindi districts as similarly vulnerable. The close similarity of the average overall indexed values of LSVI for both districts was partially due to similar average pre-indexed values for percentage of farmers entirely dependent on agriculture and surface of the cultivated land for Chakwal and Rawalpindi districts. The remaining part can be explained by lower average preindexed value for family members working outside the community but higher average pre-indexed value for agricultural livelihood diversification index in Chakwal compared with Rawalpindi district, which balanced the average overall indexed values of LSVI for both districts. The lower percentage of farmers, exclusively males, working outside the community in Chakwal district was due to the age limitation of the respondents (mostly 16 and 64 years) not allowing them to get employed in off-farm activities. The higher average pre-indexed value for agricultural livelihood diversification index in Chakwal district was mostly due to a higher number of years of employment in agriculture providing the farmers with better skills needed for diversifying agricultural production, on one hand, and the lower income generated from these activities compared with income generated from off-farm activities. Therefore, the respondents from Chakwal district, and to the lower extent from Rawalpindi district, grew crops but also raised livestock and poultry and sold the production surplus on the nearby markets to diversify their income.

The results for KSVI indicated Chakwal as more vulnerable compared with Rawalpindi district. The higher average overall indexed value of KSVI in Chakwal district was mostly due to higher average pre-indexed values for the percentage of farmers who thought they lacked education and the percentage of farmers not having TV. The higher percentage of farmers who thought they lacked education in Chakwal district can be explained by the considerably higher percentage of household heads without education compared with Rawalpindi district. Therefore, the respondents from Chakwal district might have more narrow perspectives on livelihood issues and fewer 
opportunities for improving their living conditions by, for example, adopting new agricultural techniques (Kalinda, 2014; Aasoglenang and Bonye, 2013). There is a need to educate the farmers to cope with the climatic stressors and protect their livelihoods from environmental hazards (Hsueh and Su, 2017).

The results for FiVI indicated Rawalpindi as less vulnerable compared with Chakwal district. The higher average overall indexed value of FiVI for Rawalpindi district was mostly due to the considerably higher pre-indexed values for the percentage of family members working at developed places and the percentage of farmers who took a loan. The higher values were due to a higher percentage of family members working outside the community, and having higher income, but also a higher percentage of farmers taking loans. The social mobility outside the community in Rawalpindi district may have been an attempt to ensure the financial security for the time being and future (Snel and Staring, 2001). One of the main reason for which financial component showed such effect on vulnerability was a much higher percentage of farmers in Chakwal reporting higher expenses than income and taking loans compared with Rawalpindi district. However, the average pre-indexed values for the percentage of farmers taking loans were rather low for both districts, due to the high-interest rates, terms and conditions for receiving loans, and low availability of appropriate institutions in rural areas.

The higher average pre-indexed value for the percentage of households having more expenses than income in Chakwal district was mostly due to the large percentage of the respondents employed in low-income activities, compared with Rawalpindi district. The results for FVI indicated Rawalpindi as more vulnerable compared with Chakwal district. The higher average indexed value of FVI in Rawalpindi district was mostly due to considerably higher average pre-indexed values for the percentage of farmers who did not save crop products and seeds. These higher values can be explained by a higher percentage of farmers employed in off-farm work in Rawalpindi district, on one hand, and by a higher percentage of self-sufficient farmers employed in agriculture in Chakwal district. Therefore, the lower average pre-indexed value for the percentage of farmers totally dependent on land for food in Rawalpindi district. The similarity of average pre-indexed value for average crop diversity index was due to similar crops in both districts.

The results for HVI indicated Chakwal and Rawalpindi district similarly vulnerable. The close similarity of average overall indexed values of HVI for both districts was mostly due to average pre-indexed values for the percentage of household family members with chronic diseases - higher in Chakwal and lower in Rawalpindi district; the percentage of farmers receiving treatment in hospitals - lower in Chakwal and higher in Rawalpindi district; and the time needed to reach the hospital - higher in Chakwal and lower in Rawalpindi district, all contributing to balanced average overall indexed values of HVI for both districts. The slightly lower values for Rawalpindi district were likely due to increased availability of health facilities.

The results for WVI indicated Chakwal as more vulnerable compared with Rawalpindi district. The higher average overall indexed value for WVI in Chakwal district was mostly due to higher average pre-indexed values for percentage of households without water supply, in particular, and, implicitly, the percentage of farmers utilizing natural water sources (i.e. rainwater). The considerably lower corresponding values for Rawalpindi district can be explained by additional income from off-farm activities allowing for investments inadequate farm endowments. Surprisingly, the pre-indexed average values were lower for the percentage of farmers 
storing water and the percentage of households with a depleted water source in Chakwal district. However, no conflict was reported and observed in Chakwal and Rawalpindi districts due to heavy reliance on the rainfall, and, to some extent, the existence of wells ensuring subsistence water supply in the area.

The results for SNVI indicated Chakwal as more vulnerable compared with Rawalpindi district. The higher average overall indexed value of SNVI for Chakwal district was mostly due to considerably higher average pre-indexed value for the percentage of households not affiliated with any organization such as governmental or non-governmental agricultural organizations. These types of organizations are known for their contribution to social capital through knowledge and information transfer, as well as technical support to farmers (Eakin and Bojorquez-Tapia, 2008). The low average pre-indexed values for the ratio of farmers receiving and giving help and the ratio of farmers lending money in both Chakwal and Rawalpindi districts indicated the weakness of social networks. This weakness was found to contribute to increased livelihood vulnerability (Thomas et al., 2005). Therefore, the weakness of social networks, as an aggregate component of LVI, LVI-IPCC, and LEI (Tables 1, 2 and 3), is majorly important to reducing livelihood vulnerability and farmers' vulnerability to climate change mostly through enabling the adoption of appropriate mitigating strategies (Hahn et al., 2009). However, the similarly high values for borrowing and lending money components indicate rather stable social networks in both districts.

The results for NVCVVI indicated Rawalpindi as more vulnerable compared with Chakwal district. The higher average overall indexed value of NVCVVI for Rawalpindi district was due to considerably higher average pre-indexed values of all subcomponents, except the percentage of farmers not receiving warnings regarding severe weather, compared with Chakwal district. However, all the average pre-indexed value of NVCVVI sub-components were considerably high for both districts. Ahmad et al. (2010) also reported increases in temperature and unusual trend in rainfall for the last five to ten years in both districts. While in another study, Baniasadi et al. (2016) realized that less ground water reserves, low vegetation cover, soil erosion and increased flooding are some of the worst environmental externalities. Nevertheless, these calculated values, based on farmers' inaccurate estimates (Fowler, 2002), need to be compared with values from a natural hazard database at the district level for more accurate prediction of their impact on livelihood vulnerability (Hahn et al., 2009).

The results for the average indexed value of LVI indicated Rawalpindi as slightly more vulnerable concerning livelihood compared with Chakwal district. This was mostly due to higher average indexed values for NVCVVI, lower average indexed values for SNVI and SDPVI. The major components of LVI indicate household characteristics as contributing most to climate change vulnerability in both districts. Among these characteristics, the gender of household head, family size, dependency ratio, and illiteracy level registered values indicating Chakwal district as being sociodemographically highly vulnerable compared with Rawalpindi.

\section{Livelihood Vulnerability Index-Intergovernmental Panel for Climate Change (LVI- IPCC)}

The results for the average overall indexed value of LVI-IPCC indicated Chakwal and Rawalpindi district as similarly vulnerable to climate changes. This was due to similar average pre-indexed values for exposure and sensitivity. The higher average preindexed value for the adaptive capacity in Rawalpindi district was likely due to reduced 
vulnerability in terms of socio-demographic profile, social networks, and financial situation. Moreover, considerably higher average indexed values for exposure compared with average indexed values for adaptive capacity in both districts indicated their high vulnerability to climate change and their low capacity to adapt to climate changes (González Botero et al., 2013). Moreover, adoption of strategies towards mitigation of climate changes seems to be less possible by the respondents in Chakwal district, with higher illiteracy rate, higher dependency ratio, and higher financial vulnerability, compared with respondents in Rawalpindi district. However, Booysen et al. (2004) argued that if socio-demographic profile changes towards lower dependency ratio and reduced percentage of single-headed households, the adoption of these strategies can increase.

\section{Livelihood Effect Index (LEI)}

The results for the average overall indexed value of LEI indicated Chakwal and Rawalpindi districts as similarly vulnerable to livelihood effects. This was mostly due to closely similar average overall indexed values for natural, financial and physical capital. The slightly higher average overall indexed values for human capital in Rawalpindi was mostly due to lower vulnerability in terms of food compared with Chakwal district. The slightly higher average overall indexed values for social capital in Chakwal was mostly due to a higher vulnerability about the socio-demographic profile and social networks.

Natural and financial capital had the highest impact on the livelihoods of smallholder farmers in both Chakwal and Rawalpindi districts. These two types of capitals have been associated with increased livelihood vulnerability (Cobbinah et al., 2013). Surprisingly, the human capital, comprised of health, food, and knowledge and skills components, was associated with the lowest impact on the livelihoods of farmers in both Chakwal and Rawalpindi districts. This could be due to LEI values were based on qualitative estimations, indicating if a person is affected or not by individual factors, without quantifying these effects (Urothody and Larsen, 2010).

\section{Conclusions}

Our study has highlighted the problematic state of smallholder farmers in Pakistan, their high exposure to the climatic hazards and the earnest need to decrease both their present and future vulnerability to these dangers. Small landholdings, less innovation, low capitalization and various non-climatic stressors tend to build vulnerability however the strength components, family labor, crop expansion and indigenous knowledge cannot be depreciated. Expanding the profitability of smallholder farming systems is a big challenge that will require a critical and specialized, budgetary and political support at national and global levels. However, these indices will be helpful for planners to assess livelihood vulnerability to climate change sways in the regions of Pakistan and to create projects to reinforce the most vulnerable segments. Replication of this study in the same areas and other locations over the reality of the situation will become obvious eventually how the adaptive capacity, exposure and sensitivity of the districts change as adaptation practices started.

This research work on assessment of smallholder farmers' livelihood vulnerability to climate changes can contribute to developing effective adaptation measures and ensuring sustainable agricultural development. Such research can also provide a scientific basis for the decision-making process and risk analysis of climate change 
impacts in developing countries, where the majority of smallholder farmers, as an important social group worldwide, are located.

Acknowledgements. We thank Mr. Muhammad Muqaddas and Syed Shah Mohioudin Gillani for their support in conducting surveys in both districts. This research was carried out under scholarship grant from China's National Social Science Funding in 2014, code \#14DA064.

\section{REFERENCES}

[1] Aasoglenang, A. T., and Bonye, S. Z. (2013): Rural Livelihoods Diversity: Coping Strategies in Wa West District in Northern Ghana. - European Scientific Journal 9.

[2] Adger, W. N. (2006): Vulnerability. - Global Environmental Change 16: 268-281.

[3] Ahmad, S. S., Sherazi, A., Shah, M. T. A. (2010): A Preliminary Study on Climate Change Causing Decline in Forest Cover Area in District Chakwal, Pakistan. - Pak. J. Bot. 42: 3967-3970.

[4] Ahmed, M. N., Schmitz, P.M. (2015): Climate Change Impacts and the Value of Adaptation-Can Crop Adjustments Help Farmers in Pakistan? - International Journal of Global Warming 8: 231-257.

[5] Ashley, C., Carney, D. (1999): Sustainable Livelihoods: Lessons from Early Experience. - Department for International Development London.

[6] Ashraf, M., Kahlown, M., Ashfaq A. (2004): Impact Evaluation of Water Resources Development in the Command Area of Small Dams. - Pakistan Council of research in Water Resources (PCRWR), Islamabad.

[7] Baniasadi, M., Zare M. R., Mehrjordi, Mehrabi Boshrababdi, H., Mirzaei H. R., Rezaei Estakhrooye, A. (2016): Assessing the Environmental Externalities of Excessive Groundwater Withdrawals Using the Choice Experiment Method-a Case Study of Kerman, Iran. - Applied Ecology and Environmental Research 14: 683-696.

[8] Bhat, P. N. M., Arnold, F., Gupta, K., Kishor, S., Parasuraman, S., Arokiasamy, P., Singh, S. K., Lhungdim, H. (2007): National Family Health Survey (Nfhs) III, 20052006, India, - International Institute for Population Sciences (IIPS) and Macro International. http://dhsprogram.com/pubs/pdf/FRIND3/FRIND3-Vol1andVol2.pdf, 765.

[9] Booysen, F. L. R., Bachmann, M., Matebesi, Z., Meyer, J. (2004): The Socio-Economic Impact of Hiv/Aids on Households in South Africa: Pilot Study in Welkom and Qwaqwa. Free State Province.

[10] Burch, D., Lawrence, G., Green, G., Ichijo, K., Nonaka, I., Pimentel, M., Bower, J., Gilbert, C., Couto Filho, V., Flavio, L. (2007): World Development Report 2008: Agriculture for Development. - The World Bank.

[11] Cobbinah, P. B., Black, R., Thwaites, R. (2013): Dynamics of Poverty in Developing Countries: Review of Poverty Reduction Approaches - Journal of Sustainable Development 6: 25.

[12] Corbett, J. (1988): Famine and Household Coping Strategies. - World development 16: 1099-1112.

[13] Cornish, G. (1998): Modern Irrigation Technologies for Smallholders in Developing Countries. - Intermediate Technology Publications Ltd (ITP).

[14] Csaki, C., Haan, C.d. (2003): Reaching the Rural Poor: A Renewed Strategy for Rural Development. - World Bank Publications.

[15] DHS (2006): Measure Dhs: Model Questionnaire with Commentary. - Basic Documentation, 2.

[16] Eakin, H., Bojorquez-Tapia, L. A. (2008): Insights into the Composition of Household Vulnerability from Multicriteria Decision Analysis. - Global Environmental Change 18: 112-127. 
[17] Farooq, O., Wasti, S. E. (2015): Agriculture - Pakistan Economic Survey 2014-2015. Ministry of Finance, Islamabad, Pakistan, 23-44.

[18] Fowler, F. (2002): Survey Research Methods. - Applied social research methods series (1) Show all parts in this series.

[19] Gebru, G. W., Beyene, F. (2012): Rural Household Livelihood Strategies in DroughtProne Areas: A Case of Gulomekeda District, Eastern Zone of Tigray National Regional State, Ethiopia. - Journal of Development and Agricultural Economics 4: 158-168.

[20] González Botero, D., Ariza-Montobbio, P., Reyes García, V., Serrano Tovar, T., Bertran Salinas, A. (2013): Assessing Farmers' Vulnerability to Climate Change.

[21] Green, M. (2006): Representing Poverty and Attacking Representations: Perspectives on Poverty from Social Anthropology. - The Journal of Development Studies 42: 11081129.

[22] Hahn, M. B., Riederer, A. M., Foster, S. O. (2009): The Livelihood Vulnerability Index: A Pragmatic Approach to Assessing Risks from Climate Variability and Change - a Case Study in Mozambique. - Global Environmental Change 19: 74-88.

[23] Hsueh, S. L., Su, F. L. (2017): Discussion of Environmental Education Based on the Social and Cultural Characteristics of the Community-an Mcdm Approach. - Applied Ecology and Environmental Research 15(2): 183-196.

[24] IFAD, U. (2013): Smallholders, Food Security and the Environment. Rome: International Fund for Agricultural Development.

[25] Ijaz, S., Ahmad, S. (2006): New Ideas for Potwar Agriculture. - University of Arid Agriculture, Rawalpindi, Agri Overview. www. pakissan. com.

[26] Kalinda, T. (2014): Multiple Shocks and Risk Management Strategies among Rural Households in Zambia's Mazabuka District. - Journal of Sustainable Development 7: 52.

[27] Khajuria, A., Ravindranath, N. (2012): Climate Change Vulnerability Assessment: Approaches Dpsir Framework and Vulnerability Index. - Journal of Earth Science \& Climatic Change, 2012.

[28] Lin, E., Yinlong, X., Shaohong, W., Hui, J., Shiming, M. (2007): China's National Assessment Report on Climate Change (II): Climate Change Impacts and Adaptation. Science Press, 182-200.

[29] Makondo, C. C., Chola, K., Moonga. B. (2014): Climate Change Adaptation and Vulnerability: A Case of Rain Dependent Small-Holder Farmers in Selected Districts in Zambia. - American Journal of Climate Change 3: 388

[30] McDowell, J. Z., Hess J. J. (2012): Accessing Adaptation: Multiple Stressors on Livelihoods in the Bolivian Highlands under a Changing Climate. - Global Environmental Change 22: 342-352.

[31] Morton, J. F. (2007): The Impact of Climate Change on Smallholder and Subsistence Agriculture. - Proceedings of the national academy of sciences 104: 19680-19685.

[32] Nagayets, O. (2005): Small Farms: Current Status and Key Trends. - The future of small farms. 355.

[33] O'Brien, K., Leichenko, R., Kelkar, U., Venema, H., Aandahl, G., Tompkins, H., Javed, A., Bhadwal, S., Barg, S., Nygaard, L. (2004): Mapping Vulnerability to Multiple Stressors: Climate Change and Globalization in India - Global Environmental Change 14: 303-313.

[34] Pakistan-Bureau-of-Statistics (2010): Punjab Province Tabulation; Agricultural Census 2010 - Pakistan Report http://www.pbs.gov.pk/content/agricultural-census-2010pakistan-report.

[35] Parry, M., Canziani, O., Palutikof, J., Linden, P. v.d., Hanson, C. (2007): Climate Change 2007: Impacts, Adaptation and Vulnerability. Contribution of Working Group II to the Fourth Assessment Report of the Intergovernmental Panel on Climate Change. Summary for Policymakers. - Climate change 2007: Impacts, Adaptation and Vulnerability. Contribution of Working Group II to the Fourth Assessment Report of the Intergovernmental Panel on Climate Change. Summary for Policymakers. 
[36] Rafique, S. (2015): Punjab Development Statistics. Bureau of Statistics Government of the Punjab Lahore. - http://bos.gop.pk/system/files/Dev-2015.pdf, 414.

[37] Rosch, S. D., Hertel, T. W. (2010): Climate Change, Agriculture and Poverty.

[38] Sanchez, P. A., Swaminathan, M. S. (2005): Cutting World Hunger in Half. - Science 307: 357.

[39] Sheikh, M. S. (2012): District Pre-Investment Study - 2012; Chakwal. - Directorate of Industries, Punjab Poonch House, Multan Road, Lahore, 1-62.

[40] - (2012): District Pre-Investment Study - 2012; Rawalpindi. - Directorate of Industries, Punjab Poonch House, Multan Road, Lahore, 1-77.

[41] Snel, E., Staring, R. (2001): Poverty, Migration, and Coping Strategies: An Introduction. - Focaal European journal of anthropology 38: 7-22.

[42] Sullivan, C. (2002): Calculating a Water Poverty Index. - World development 30, $1195-$ 1210.

[43] Tan, M. (2004): Global Climate Change: The Challenges Confronted by Humanity. - The National Climate Change Countermeasures Coordination Team Office and The Management Center of China Agenda for the $21^{\text {st }}$ Century. The Commercial Press, 333.

[44] Tao, S., Xu, Y., Liu, K., Pan, J., Gou, S. (2011): Research Progress in Agricultural Vulnerability to Climate Change. - Advances in Climate Change Research 2: 203-210.

[45] Tewari, H. R., Bhowmick, P. K. (2014): Livelihood Vulnerability Index Analysis: An Approach to Study Vulnerability in the Context of Bihar. - Jàmbá: Journal of Disaster Risk Studies 6: 13.

[46] Thomas, D., Osbahr, H., Twyman, C., Adger, N., Hewitson, B. (2005): Adaptive: Adaptations to Climate Change Amongst Natural Resource-Dependant Societies in the Developing World: Across the Souther African Climate Gradient. Tyndall Centre for Climate Change Research.

[47] Tripathi, S., Vasan, A. (2014): Climate Change Vulnerability Assessment Framework for Sustainable River Basin Management. - Available at SSRN 2501242.

[48] Urothody, A., Larsen, H. (2010): Measuring Climate Change Vulnerability: A Comparison of Two Indexes. - Banko Janakari 20: 9-16.

[49] Van der Berg, S. (2002): Education, Poverty and Inequality in South Africa. - Paper to the Conference of the Centre for the Study of African Economies, on Economic Growth and Poverty in Africa, Oxford, 1-26.

[50] Von Braun, J., Pandya-Lorch, R. (2007): Taking Action for the World's Poor and Hungry People: Synopsis of an International Consultation. Intl Food Policy Res Inst.

[51] Yu, W., Yang, Y. C., Savitsky, A., Alford, D., Brown, C. (2013): The Indus Basin of Pakistan: The Impacts of Climate Risks on Water and Agriculture. - World Bank Publications. 